\title{
Why Do Russians Support Censorship of the Media?
}

\section{Pietiläinen, Jukka}

2010

Pietiläinen , J \& Strovsky , D 2010 , ' Why Do Russians Support Censorship of the Media? ' , Russian Journal of Communication, vol. 3 , no. 1-2, pp. 53-71 .< http://www.marquettejournals.org/images/RJCVol3Nos1-2.pdf >

http://hdl.handle.net/10138/24366

acceptedVersion

Downloaded from Helda, University of Helsinki institutional repository.

This is an electronic reprint of the original article.

This reprint may differ from the original in pagination and typographic detail.

Please cite the original version. 


\title{
WHY DO RUSSIANS SUPPORT CENSORSHIP OF THE MEDIA?
}

\section{Jukka Pietiläinen and Dmitry Strovsky ${ }^{1}$}

\begin{abstract}
This article analyses support for censorship in Russia as part of the democratization process. Censorship has been an important part of Russian history and it was strengthened during the Soviet era. After the collapse of the Soviet system formal censorship was banned even though the reality has been different. Therefore it is not strange that many Russians would like to limit the freedom of the media and to censor certain topics. The views of Russians on censorship have been studied on the basis of a survey carried out in 2007. According to the results, three different dimensions of censorship were found. These dimensions include moral censorship, political censorship, and censorship of religious materials. Support for these dimensions varies on the basis of socio-demographic characteristics and media use. The article concludes that many Russians reject new phenomena, while support for the censorship of political criticism is not as high, but political censorship seems to enjoy more support among elites than among the common people.
\end{abstract}

Keywords: Russia, censorship, public opinion, mentality, social change, media

Public support for democratic values has been seen as an important part of the democratization process. If people tend to see democracy and democratic institutions in a negative light, they may easily support authoritarian movements which may turn back the democratization process. Freedom of speech and the press belong to the most important institutions of a democracy, and in order to survive they need popular support. Since an independent media did not exist in the Soviet Union, these freedoms have been weak and their development has been slow. In the 1990s

\footnotetext{
${ }^{1}$ Jukka Pietiläinen is a media researcher at the Aleksanteri Institute of the University of Helsinki and a docent of journalism and mass communication at the University of Tampere (jukka.pietilainen@helsinki.fi). Dmitry Strovsky is professor of media history at the Journalism Faculty of the Ural State University, Russia (strovsky@mail.ru).
} 
many journalists and media ended up with paid-articles which destroyed public trust in the media, and few protested when the state silenced critical television channels after 2000. If people do not see the value of a pluralist, uncensored media they may easily support, or approve, government policies which limit the freedom of speech.

The concept of an "authoritarian personality" was launched in the 1950s (Adorno, FrenklBrunswik, Levinson \& Sanford, 1950) and since then both right-wing and left-wing authoritarian individuals have been seen as a threat to democratic regimes, and even though criticism has been directed at this concept and the authoritarian personality has been seen to be in decline in postmodern societies, the links between individual beliefs and political outcomes have been widely studied. Former studies in post-Soviet Russia have been found that "authoritarianism strongly predicted support for reactionary leaders and military actions and opposition to democratic and nonRussian leaders and to democratic activities" (McFarland, Ageyev \& Abalakina-Paap, 1992, p. 1004).

In this article we pay attention to one aspect of authoritarian political thinking, namely, the support for censorship, and analyse how support for censorship is structured in Russia and what kind of materials post-Soviet Russians would like to censor and why. It is worth noticing that attitudes to censorship have been widely studied in the United States (see Lambe, 2002, for a comprehensive review), while this kind of research has been very limited, if it has been conducted at all, in other countries, especially in Western Europe. Therefore, this study about Russia will also offer opportunities for international comparisons.

\section{Censorship in Czarist Russia and in the Soviet Union}

In the Czarist era, censorship was inseparable from the political background of the society and was actively cultivated by the monarchy. The political will of the tsar was always considered indisputable by most people, and therefore the proclaimed "rules of the game" seem to have been a strong priority for the nation. Censorship was consistently promoted by czars without the agreement of political bodies. The first Russian newspaper, Vedomosti, was founded by Peter the Great in 1702 and was personally edited by him for over two decades. In fact, Vedomosti was not a specific kind of a publication and resembled more a PR instrument than a newspaper as traditionally understood in the West.

Although historical sources indicate great changes were underway with regard to censorship in the early twentieth century compared to previous centuries, this, in fact, concerned mostly political plurality, not the printed word. True, there existed a larger variety of newspapers at that time, but any publication critical of the political system was unwelcome. With some exceptions, the Bolshevik press was undermined for most of the early twentieth century, until Lenin and his comrades came to power in 1917. 
The Soviet period inherited many political traditions from the preceding society. One of these legacies was undoubtedly the existence and enforcement of censorship.

As early as December 1918, the Revolutionary Military Council of the Russian republic enacted the Statute of Military Censorship. In June 1922, a new body inherited all censoring authorities: Glavlit (Glavnoe upravlenie po delam literatury i izdatelstv — The Main Administration for Literary and Publishing Affairs). Glavlit censored all printed materials, photographic materials, and books. From the very beginning, Glavlit possessed vast powers. It was authorized to conduct a preliminary surveillance of all works destined for publication and distribution, including the press.

Some stages of Soviet history, the so-called "thaws" which only lasted for relatively short periods of time such as New Economic Policy under Lenin or Khrushchev's denunciation of the Stalin's legacy, demonstrated a different attitude to censorship. Nonetheless, these "thaws" did little to change the ideological principles underlying the state's existence. In Soviet society, formal censorship developed alongside political control (party supervision of the media) and precensorship by editors (Dzirkals, 1982). Censors were interested not only in repressing heretical opinions, but also in dictating what must be written (Dewhirst \& Farrell, 1973, p. 12).

\section{The Post-Soviet era: new trends?}

In the Soviet media law of 1990, formal censorship was banned even though the reality was different. There were many rules that allowed these proclaimed rules to be broken by claiming political necessity. The "inadmissibility of censorship" is also declared in the contemporary Russian media law, which was adopted in 1991 and maintains its initial traits without great changes. Censorship itself is defined as "the demand made by officials, state organs, organizations, institutions or public associations that the editor's office of a mass medium shall get in advance agreement on a message and materials (...) and also for the suppression of the dissemination of messages and materials" (Russian Mass Media Law, 1991). This definition extends the range of censorship beyond state organs. Even though formal censorship was apparently removed in postSoviet Russia, editorial freedom was limited, and therefore most Russian journalists continued to engage in self-censorship (Belin, 2001, p. 341). By self-censorship we mean, to a large extent, selflimitation, that is when an author involved in different sorts of creativity has to restrain or even stop himself/herself from developing a certain idea. Self-censorship usually appears as a very specific skill in camouflaging one's thoughts in response to political, economic, and cultural circumstances. Moreover, new forms of limitations have been developed concerning the ban to spread state, military, or commercial secrets (Zhirkov, 2001, p. 349-350). Under Putin's presidency, state supervision of the most important media, especially television, has been tightened (Belin, 2002, p. 154). The state itself and its structures became pivotal censors of the content of the two main 
Russian TV-channels (First channel and Rossiia) of the state's interests. Non-criticism of state policy, initiated and developed by Russian Presidents Vladimir Putin at first and then Dmitry Medvedev, was and is strictly favored by these two TV-channels, and all other scenarios are unwelcome.

Aleksei Simonov, the Chief of the Russian Glasnost Defense Foundation, identifies six types of censorship: administrative censorship, economic censorship, censorship resulting from actions by, or threats from, criminals, censorship resulting from editorial policy, censorship resulting from editorial taste, and self-censorship (Dewhirst, 2002, p. 28-30). If tighter criteria are used, only the first of these remarks can be defined as censorship. The challenge for researchers in the Russian case is that the concept 'censorship' may be used in a much wider context than is usually the case in the West.

Many opinion polls conducted in Russia over the last few years have demonstrated a high level of support for censorship and media control among the Russian population. The most recent polls conducted by ROMIR Monitoring and the All-Russian Public Opinion Research Center (WCIOM) in the spring of 2004 and 2006 have shown that 62-63\% of Russians (WCIOM, 6.7.2004; VCIOM, 04.08.2006) and 40\% of Russian journalists (Zhurnalisty o Rossii, obshchestve i SMI, 2004, p. 11) support censorship in the mass media. To be sure, the ROMIR survey notes that a third of respondents viewed censorship as necessarily justified (obyazatel'no nuzhna), while 39\% were feeling that it is more likely to be justified (skoree nuzhna). Only $9 \%$ of respondents considered censorship unjustified (neopravdannaya), while $18 \%$ reported that censorship is unjustified only to some extent. According to WCIOM, 35\% of those interviewed thought censorship absolutely necessary (bezuslovno nuzhna), while $28 \%$ considered censorship justified to some extent $(2004 ; 2006)$.

In other polls conducted by the Public Opinion Foundation, support for censorship was lower (between $49 \%$ and 57\%) than that in the polls by ROMIR and WCIOM, but the majority of Russians supported the idea of censorship. The topics that Russians usually consider necessary to be censored include not only politics, but also sex, pornography, violence, crimes, and, perhaps surprisingly, advertising. Some respondents added to these topics art forms, entertainment, and feature films (Monitoring obshchestvennogo mneniya, 2004, p. 93-94).

\section{Research material, methods, and results}

To determine why and to what extent Russians today are inclined to support censorship, a question on censorship was included in a survey of the Russian population commissioned by a group of Finnish researchers (Nikula \& Chernysh, 2010). 
Table 1

Opinion about Banning Various Types of Information

\begin{tabular}{|c|c|c|c|c|}
\hline & Banned & $\begin{array}{l}\text { Released with } \\
\text { limitations }\end{array}$ & $\begin{array}{l}\text { Circulated } \\
\text { freely }\end{array}$ & Hard to say \\
\hline Criticism of the President of Russia & $11.4 \%$ & $37.9 \%$ & $37.2 \%$ & $13.4 \%$ \\
\hline Materials against an ethnic group or race & $52.6 \%$ & $30.0 \%$ & $7.6 \%$ & $9.7 \%$ \\
\hline Materials glorifying communism & $31.6 \%$ & $33.0 \%$ & $17.3 \%$ & $18.1 \%$ \\
\hline Negative information, "the dark side of reality" & $66.9 \%$ & $23.5 \%$ & $3.5 \%$ & $6.0 \%$ \\
\hline Information on sexual minorities, homosexuals & $61.5 \%$ & $28.7 \%$ & $3.8 \%$ & $5.9 \%$ \\
\hline Materials on sects, non-traditional religions & $51.6 \%$ & $34.7 \%$ & $7.1 \%$ & $6.5 \%$ \\
\hline Depiction of violent scenes & $77.8 \%$ & $17.2 \%$ & $1.8 \%$ & $3.2 \%$ \\
\hline Openly erotic materials, naked bodies & $54.8 \%$ & $36.4 \%$ & $4.2 \%$ & $4.6 \%$ \\
\hline Religious propaganda & $25.0 \%$ & $43.7 \%$ & $18.8 \%$ & $12.5 \%$ \\
\hline Advertisements & $36.7 \%$ & $53.7 \%$ & $3.9 \%$ & $5.7 \%$ \\
\hline
\end{tabular}

The Institute of Sociology of the Russian Academy of Sciences carried out the survey in February 2007 in 52 locations in Russia under the supervision of Mikhail Chernysh. The data were collected by geographical cluster sampling. The locations in which the interviews took place ranged from Moscow to small villages in the Far East as well as to non-Russian republics. The total number of respondents was 2,014 .

The question on censorship was divided into ten different categories, partly on the basis of earlier research and opinion polls, partly on the basis of researchers' decision. Even if the list of the topics suggested is far from complete, it nevertheless offers an opportunity to analyse support for censorship in detail. The support for censorship for each content category was measured on a threepoint scale. These are 1) information should be banned; 2) information should be published with limitations, and 3) information should be freely disseminated. Between $3 \%$ and $18 \%$ of the respondents chose the fourth option, "hard to say". The lowest figure for those having no opinion occurred with regard to the censorship of violence, and the highest, regarding materials glorifying communism. The last category was included in order to find out if there were people who would like to ban the praising of the former regime, but are liberals concerning other topics. 
Table 2

Five Groups of Censorship Supporters

\begin{tabular}{|c|c|c|c|c|c|}
\hline & Liberals & $\begin{array}{l}\text { Supporters of } \\
\text { partial censorship }\end{array}$ & $\begin{array}{l}\text { Supporters of censorship } \\
\text { of religious materials }\end{array}$ & $\begin{array}{l}\text { Supporters of } \\
\text { political censorship }\end{array}$ & $\begin{array}{l}\text { Supporters of hard- } \\
\text { line censorship }\end{array}$ \\
\hline$\%$ of total & $6 \%$ & $25 \%$ & $22 \%$ & $19 \%$ & $28 \%$ \\
\hline Men & $61 \%$ & $57 \%$ & $47 \%$ & $40 \%$ & $43 \%$ \\
\hline $\begin{array}{l}\text { Living in big } \\
\text { cities }\end{array}$ & $40 \%$ & $22 \%$ & $20 \%$ & $20 \%$ & $12 \%$ \\
\hline $\begin{array}{l}\text { Under } 30 \\
\text { years of age }\end{array}$ & $35 \%$ & $33 \%$ & $19 \%$ & $10 \%$ & $17 \%$ \\
\hline Low income & $15 \%$ & $15 \%$ & $22 \%$ & $24 \%$ & $21 \%$ \\
\hline $\begin{array}{l}\text { High } \\
\text { education }\end{array}$ & $32 \%$ & $28 \%$ & $21 \%$ & $20 \%$ & $18 \%$ \\
\hline
\end{tabular}

In general, support for censorship was high (Table 1): the average figures for the ten issues were $47 \%$ for total censorship, $34 \%$ for partial limitation, and only $11 \%$ for free dissemination. On the other hand, the topics were selected so that they would have yielded significant support for censorship.

The results indicate that censorship of political topics, represented in this study with the banning of criticism of the Russian President, is rather unpopular in Russia. Only a few people favor a total ban; the rest of the respondents were divided almost equally between those supporting free dissemination and those supporting partial limitations. On the other hand, the majority would like to suppress other topics, including those not occurring in the Soviet media, such as nudity, information on sexual minorities and on new religious movements.

Cluster analysis reveals that Russians could be divided into five different groups according to their support for censorship (Table 2). Initially, a small group of liberally-minded people emerges who almost completely oppose censorship. On the opposite side of the spectrum is a rather large group supporting extensive censorship. Quite close to the liberals is a third group consisting of "middle-way" people who hold neither strictly pro-censorship nor strictly anti-censorship views, but would impose limitations on some specific cases. In addition, two groups are usually pro-censorship but along stricter lines, firstly, with regard to religious materials and, secondly, with regard to political materials. 
The first, most liberal, group comprises only $6 \%$ of Russians. They oppose most forms of censorship and would at most like to censor only explicit scenes of violence, advertisements and nudity. They are mainly men, often younger than 30 years of age and live mainly in Moscow and some other major cities.

The second group is comprised of people choosing the middle option of selective control. The majority of this group supports only a ban on the portrayal of violence. The third and fourth groups differ from the others with regard to certain materials. The supporters of censorship of religious materials would like to limit religious propaganda and information about new religious movements, but would have allowed criticism of the Russian President and materials glorifying communism. Another group supporting selective censorship comprises supporters of political censorship; they would not seek to limit religious propaganda, but would like to limit criticism of the Russian President and materials glorifying communism. The supporters of censorship of religious materials are also younger than the supporters of political censorship; old women especially prefer political censorship to censorship of religious materials.

The supporters of hard-line censorship would like to ban most topics from being published. Only criticism of the Russian President and advertisements are not unanimously supported. Hardline censorship is the most common type among women over 30 and men over 60 years old. This finding is well in line with former studies on values in Russia. Ellen Garnaghan, for example, has learned that Russians "who were more willing to give up freedom often thought they had very little freedom to start with" (Garnaghan, 2007, p. 180). Remarkable differences on the basis of age were found by Mishler and Rose (2007), who came to the conclusion that such differences were caused by socialization under different social conditions.

The more liberal groups include those people who are better educated, younger and who have higher incomes. The liberals and supporters of partial censorship are also the groups with a majority of men. The supporters of hard-line censorship can mostly be found in rural areas and in towns with a population of less than one million inhabitants.

Different categories of censorship correlated positively with each other. The highest correlation (.50) could be found between the censorship of information on sexual minorities and the censorship of materials about non-traditional religions. The weakest correlation (.065) occurred between censorship of advertisements and the censorship of criticism of the Russian president. Also, correlations between the censorship of religious propaganda and of ethnic hatred were low. Support for a censorship of religious propaganda seems to have different roots than do other types of censorship. 
Table 3

Factor Analysis of Support for Censorship

\begin{tabular}{|c|c|c|c|}
\hline Topic & $\begin{array}{l}\text { Factor } 1 . \\
\text { Moral } \\
\text { censorship }\end{array}$ & $\begin{array}{l}\text { Factor } 2 . \\
\text { Political } \\
\text { censorship }\end{array}$ & $\begin{array}{l}\text { Factor } 3 . \\
\text { Censorship of } \\
\text { religious materials }\end{array}$ \\
\hline Information on sexual minorities & .76 & & \\
\hline Explicit scenes of violence & .76 & & \\
\hline Undisguised erotic, naked bodies & .70 & & \\
\hline Negative information & .67 & .35 & \\
\hline $\begin{array}{l}\text { Materials on sects and non-traditional } \\
\text { religions }\end{array}$ & .56 & & .42 \\
\hline Criticism of the Russian President & & .69 & \\
\hline Materials glorifying communism & & .68 & .37 \\
\hline Materials against an ethnic group or race & .46 & .56 & \\
\hline Religious propaganda & & & .81 \\
\hline Advertisements & .30 & & .50 \\
\hline Of total variance explained & $32.5 \%$ & $11.8 \%$ & $10.6 \%$ \\
\hline
\end{tabular}

Varimax rotation with Kaiser normalization. Values below 0.30 have been omitted.

\section{Elements of censorship}

The factor analysis suggests three different dimensions of censorship; for further analysis the ten topics of censorship were reduced to three factors, of which the components appear in Table 3.

The first of these factors most clearly includes topics such as information on sexual minorities, explicit scenes of violence, and erotic materials. These clearly reflect the moral nature of censorship. The second factor comprises mainly censorship of criticism of the Russian President, of materials glorifying communism, and of materials against an ethnic group. This factor represents the political nature of censorship.

The third factor is represented most clearly by religious propaganda, followed by the censorship of advertisements. Also, materials on sects and non-traditional religions as well as materials glorifying communism receive a rather high loading on this factor. Therefore, this element of censorship may not reflect anti-religious and anti-capitalist Soviet thinking, but rather a more modern anti-religious and anti-market thinking. 
As studies in the United States have found (Lambe, 2004), censorship of pornography and censorship of hate speech are two different elements of censorship. In Russia, however, this distinction is not as clear as in the United States, since censorship of materials against an ethnic group or race is also partly represented in the moral censorship factor.

The background variables affecting the support for each of these types of censorship, differ somewhat, and in some cases, are even opposite.

As Table 4 shows, the three types of censorship are based partly on different background variables. The three trust variables in the table have been counted with factor analysis on the basis of trust in 15 different institutions. In addition, identity variables have been counted with factor analysis by factoring a group of statements on identity with which the respondents could agree or disagree.

In addition to background variables, media use and media-related attitudes also have an impact on support for censorship. Actually, most of these media-use habits reflect support for censorship mostly on the basis of the different media use habits of different age or other groups. Therefore, reading Cosmopolitan or watching MTV may have no direct links to decreased support for censorship, but rather such media are targeted at young people, who generally support censorship of moral issues less than older people, who seldom read Cosmopolitan or watch MTV.

On the other hand, these media-use habits may be connected to censorship attitudes. For example, it seems reasonable that people who read Cosmopolitan and watch entertainment TV channels STS and TNT may oppose moral censorship more than others, even though one must note that such media use habits have less influence than age. The causality may even work in the opposite direction: supporters of moral censorship may be less likely to read Cosmopolitan or to watch entertainment TV according to their attitudes to censorship. When correlations are counted separately for each age group, reading Cosmopolitan and watching STS appear to bear a significant relationship to support for moral censorship only among people aged 40 to 49 . The correlations concerning the groups of different ages are positive, but statistically insignificant.

The results suggest that media-use habits are based on age, which also explains both the attitude towards moral censorship and media use. The impact of a particular type of media use on censorship attitudes appears only in some population groups.

\section{Moral censorship}

The most important predictor for moral censorship is age. The young support moral censorship less than older people. The clearest difference is in the willingness of the latter to support censorship of erotic materials: support for censorship decreases almost exactly 10 percentage points per ten years of age (see table 6). Willingness to support censorship of violence 
Table 4

Significant Correlations between Background Variables and Different Types of Censorship

\begin{tabular}{|c|c|c|c|}
\hline Background variable & $\begin{array}{l}\text { Moral } \\
\text { censorship }\end{array}$ & $\begin{array}{l}\text { Political } \\
\text { censorship }\end{array}$ & $\begin{array}{l}\text { Censorship of } \\
\text { religious materials }\end{array}$ \\
\hline Age & $.33^{* *}$ & $-.06 *$ & $-.08 * *$ \\
\hline Gender (male) & $-.15^{* *}$ & $-.06 * *$ & $.08^{* *}$ \\
\hline $\begin{array}{l}\text { Type of settlement }(1=\text { Moscow, } 9=\text { small } \\
\text { village) }\end{array}$ & $.14 * *$ & $.13^{* *}$ & \\
\hline Education & $-.11 * *$ & & $-.06^{*}$ \\
\hline Has children & $.23 * *$ & & $-.05 *$ \\
\hline Family size (living together) & & & $-.06 *$ \\
\hline Respondent's family income & $-.14 * *$ & & \\
\hline Self-perceived level of well-being & $-.15^{* *}$ & $.06 *$ & \\
\hline Change in well-being since 2000 & $-.10^{* *}$ & $.09 * *$ & \\
\hline Economic optimism & $-.12 * *$ & $.09 * *$ & \\
\hline Increase in spending for medical services & $.15^{* *}$ & $-.12 * *$ & \\
\hline Increase in spending for food & $.13^{* *}$ & $-.06 *$ & \\
\hline $\begin{array}{l}\text { Increase in spending for municipal } \\
\text { payments }\end{array}$ & $.12 * *$ & $-.07 *$ & \\
\hline Position in managerial hierarchy & & $.08 *$ & $-.10 * *$ \\
\hline Speaks a foreign language & $-.13 * *$ & & $-.07 * *$ \\
\hline Trusts state institutions & & $.10^{* *}$ & \\
\hline Trusts civil society (including the media) & $-.14 * *$ & $.12 * *$ & \\
\hline Trusts army and church & $.14^{* *}$ & & $-.16^{* *}$ \\
\hline Ethnic non-Russian & $.09 * *$ & & $-.06 *$ \\
\hline Identity: regional and ethnic & $.13 * *$ & & $-.10 * *$ \\
\hline Identity: world citizen & $-.14 * *$ & & $.07 * *$ \\
\hline Identity: USSR & & $-.08 * *$ & \\
\hline Believes in God & $.08 * *$ & $.08 * *$ & $-.13 * *$ \\
\hline Orthodox believer & & & $-.09 * *$ \\
\hline
\end{tabular}

$* *=$ correlation is significant at the 0.01 level;

$*$ = correlation is significant at the 0.05 level. 
Table 5.

Media Use and Support for Censorship

\begin{tabular}{|c|c|c|c|}
\hline Background variable & Moral censorship & Political censorship & $\begin{array}{l}\text { Censorship of } \\
\text { religious materials }\end{array}$ \\
\hline Read newspapers & $.13 * *$ & & $-.10 * *$ \\
\hline Read magazines & $-.07 * *$ & $.07 *$ & \\
\hline Listen to the radio & $-.08 * *$ & & \\
\hline Watch First channel (state) & $.11 * *$ & & $-.05 *$ \\
\hline Watch Rossiya channel (state) & $.16^{* *}$ & & $-.07 *$ \\
\hline Watch TNT channel (private) & $-.12 * *$ & & $.12 * *$ \\
\hline Watch STS channel (private) & $-.11 * *$ & & \\
\hline Watch MTV channel (private) & $-.12 * *$ & & \\
\hline Watch Kul'tura channel (state) & $.09 * *$ & & \\
\hline Watch Sport TV (state) & & $-.08 * *$ & \\
\hline Watch Ren-TV (private) & $-.07 * *$ & & \\
\hline Listen to Radio Rossii & $.11 * *$ & & \\
\hline Listen to Evropa Plus & $-.16^{* *}$ & & \\
\hline Listen to Avtoradio & $-.08 * *$ & & \\
\hline Listen to Radio Shanshon & & & $.08 * *$ \\
\hline Listen to Radio Dorozhnoe & & $-.09 * *$ & \\
\hline Listen to Ekho Moskvy & $-.05 *$ & & \\
\hline Read Komsomol'skaya pravda & $.06^{*}$ & & \\
\hline Read Liza & & $.10^{* *}$ & \\
\hline Read Cosmopolitan & $-.11 * *$ & & \\
\hline Read Sem dnei & & $.08 * *$ & -.05 \\
\hline Read Zdorov'e & & $.07 *$ & \\
\hline Internet connection at home & $-.14 * *$ & & \\
\hline Source of information: newspapers & & $.05^{*}$ & $-.11 * *$ \\
\hline Source of information: internet & $-.09 * *$ & & \\
\hline Source of information: radio & & & $.06^{*}$ \\
\hline
\end{tabular}


does not decrease with a similar tendency but it nevertheless demonstrates the lowest rate among the youngest. In addition, support for censorship of information on sexual minorities and of negative information is lower in younger age groups. In particular, those under 30 differ from all others.

This finding is well in line with generation differences in Russian society, that have been found previously. Younger Russians, whose experience of the USSR is more limited, are better adapted to the new social conditions. Therefore, they tend to accept new phenomena in society and the media better than the older generations, who have lived under completely different conditions.

Moreover, gender and income are important predictors of support for moral censorship. Women and those with low incomes are more willing to support moral censorship. The difference between men and women is usually not very great: it is highest for the censorship of erotic material $(+19 \%)$ and of negative information $(+12 \%)$. People whose families earn less than 7,500 roubles monthly are more willing to support moral censorship.

Those living in rural areas more often support moral censorship as do those with lower education. In addition, those who feel their well-being has not improved since 1998 are more willing to support moral censorship.

The impact of trust in social institutions is measured according to three dimensions. Levels of trust in 15 institutions were measured on a five point scale, and factor analysis served to reveal three dimensions of trust (trust in state institutions; trust in non-state institutions, including the media; and trust in the church and the army).

Trust in traditional institutions of authority (the army and the church) has a positive impact on support for moral censorship, but trust in civil society - including the media - has a negative impact. Various institutions seem to compete for the place of moral guidance: trust in traditional authorities opposes trust in modern institutions. Thus, those who see traditional institutions as more important tend to support censorship. Trust in state institutions has no significant impact on support for moral censorship.

In addition, media use has some impact on support for moral censorship. Those who read newspapers less often are less willing to support moral censorship, but those who read journals and listen to the radio more often are more willing to support moral censorship. The differences caused by media use actually result from different media-use habits among people of different ages. When the influence of age is controlled for, these differences disappear or become insignificant. Having an Internet connection at home also decreases one's willingness to support moral censorship. 


\section{Political censorship}

Political censorship combines the censorship of criticism of the Russian President, of praising communism, and of hatred against ethnic groups.

The most important factor behind differences favoring support for political censorship is location. Those living in the countryside are more willing to support political censorship than those living in Moscow and in towns with 100,000 to one million inhabitants. In this respect, the most liberal people can be found in St. Petersburg.

The impacts of age, income, change in well-being since 2000, and change in consumption are opposite to support for moral censorship. Those who are young, have higher incomes, whose wellbeing has improved and whose consumption of food and medical services has decreased support political censorship more often than others. The impact of age is mostly due to younger Russians' greater inclination to ban materials glorifying communism.

Women support political censorship more than men. The gender difference is greatest in support of a ban on materials against an ethnic group or race $(+6 \%)$, but is almost non-existent in the two other main categories of political censorship.

Income as such does not lead to any differences in support of political censorship, but person's self-perception of his/her economic situation has a small impact: those who feel that their economic situation is better more frequently support political censorship. This is due mainly to the fact that those with no economic problems support the censorship of materials glorifying communism more than do others and would like to at least limit, if not ban, criticism of the Russian President. In addition, those at the lower end of the economic scale support political censorship more than do middle-class economic groups.

Position in a managerial hierarchy also has a positive correlation to political censorship. About $25 \%$ of top-level managers preferred to ban criticism of the Russian President, and as many as $48 \%$ of managers supported a ban on materials glorifying communism.

Believers in God are also more prone to support political censorship. People who identify themselves as citizens of the USSR are less willing to support political censorship, mainly because they support censorship of materials glorifying communism less than others. People who identity themselves as citizens of the USSR are usually older, more often live in the rural areas and have a lower level of education.

The most important difference for moral censorship is its impact on trust in civil society. Trust in almost any institution, including the media, increases support for political censorship. In particular, trust in media and in civil society institutions (trade unions, civic organizations) and in political institutions increases in terms of a certain desire to support political censorship. This can be explained by the fact that trust in both the President and the media represents support for the 
status quo and that this trust in state authorities implies trust in granting the right to control media content to someone in a superior position.

Political censorship seems to enjoy more support among elites than among the common people. This element of censorship also includes topics such as the censorship of materials glorifying communism. It seems reasonable that elites in particular support such censorship. The orientation of elites has turned to the opposite but the attitude to alternative views has remained the same: before anticommunist materials were not tolerated, now the same attitude is focused on procommunist materials.

\section{Censorship of religious materials}

This dimension of censorship represents a way of thinking which opposes both religious propaganda and, strangely, advertising. Both are topics which did not exist in the Soviet media. In addition, materials on new religious sects and, perhaps surprisingly, those glorifying communism have a certain impact on this element of censorship.

The clearest indicator for censorship of religious materials was naturally represented by religious faith. Of believers, $24 \%$ supported censorship of religious propaganda, and $22 \%$ would like to permit it without limitations, whereas among non-believers, these figures were $29 \%$ in favor of complete censorship and only $12 \%$ in favor of the free dissemination of religious propaganda. It may seem strange that many believers support the control of religious propaganda, but they may oppose the propaganda of other religions more than that of their own or they may not define religious materials primarily as 'propaganda'.

Moreover, a respondent's position in a managerial hierarchy affects his or her support for religious censorship. Those in higher managerial positions support censorship of religious materials more than do others.

Men support this kind of censorship more than do women and the young support it more than the old. Gender and age had completely opposite effects on the censorship of religious propaganda and advertisements than on the censorship of other kinds of issues.

The banning of religious propaganda enjoys support among the younger population, but banning of advertisements has more support among people over 60. Among others, support for the banning of advertisements is relatively stable. Among people under 30, the attitude towards advertisements is the freest: as many as $41 \%$ would allow it without restrictions. On the other hand, only $12 \%$ of people under 30 would like to allow religious propaganda without restrictions.

Even though education has practically no impact on religiosity, those with a poor educational level support censorship of religious materials more actively. Those who do not use newspapers as a source of information and do not read newspapers also favor censorship of religious materials. 
Quite naturally, those who did not trust the Russian Orthodox Church seek to support censorship of religious materials. On the other hand, there were no major differences between trust in other institutions and censorship of religious materials.

While a ban on religious propaganda is supported more by non-believers than by orthodox believers, support for a ban on information concerning non-traditional religions is bolstered by orthodox believers, even though the difference is small. Also, the censorship of advertisements enjoys support among orthodox believers more often than among members of other religions and non-believers. The finding that a significant number of believers support a ban on religious propaganda can be understood as part of a certain formlessness which according to Jeffrey Alexander (1997, p. 109-110) has emerged in the post-socialist states.

\section{Discussion}

The high level of support for censorship, which has also been found in earlier studies, lends support to the idea that some elements of a totalitarian or authoritarian mindset still prevail in postSoviet Russia. As has been found earlier (Mishler \& Willerton, 2003, p. 114-115), the Russian public tends to support order and security and expect the state to take responsibility for popular well-being. It may well be that Russians also expect the state to take responsibility for decent media content and therefore tend to support censorship, even if this means state control of the media. Fear and suspicion regarding new things perhaps explain Russian attitudes to censorship even more clearly: things which did not exist in Soviet period continue to generate dissatisfaction, especially among older people who were socialized during the Soviet era.

Moreover, according to research conducted on the basis of data collected for the European Social Survey, the average Russian is characterized by a high level of cautiousness or even fear, and a high need for the protection of a strong government (Magun \& Rudnev, 2008, p. 56)

High levels of cautiousness on the one hand and trust in strong government on the other are also related to high levels of support for censorship. Fear of new things contributes to the idea that the emergence of new things should be limited, and strong support for social protection from a powerful government paves the way to censorship (by the government) as a means of restriction.

The two main elements of censorship, moral censorship and political censorship, are supported by very different, in many cases even opposing, groups of people. Moral censorship is supported more often by the elderly, women, people with low education, low social status, and people living in rural areas.

On the other hand, political censorship is supported more often by those who have gained in the transition and who are on the upper levels of the managerial hierarchy. This may have something to do with the idea that fear of freedom is part of the totalitarian mentality (Mikheyev, 
1996, p. 34) inherited from the Soviet past. The new elites have been formed partly on the basis of the old Soviet elite and have retained part of that old elite's mentality.

The high level of support for censorship, even if censorship itself is based on moral rather than political considerations, indicates that institutional learning did not develop as rapidly as Mishler and Rose (2007) found on the basis of some other variables. Moreover, when comparative data is available it tends to indicate an increase rather than a decrease in support for censorship in general.

The rather strict views on the censorship of most issues are in accordance with the trend previously identified in the less advanced countries of Eastern Europe (Russia included) that "the population feels a stronger need for stricter laws, for resisting illegal acts and organized crime," and in this case the professionals "indicate the highest degree of support for respect of the legal and institutional order" (Tilkidjiev, 2006, p. 124-125).

Increasing trust in the president and other institutions may even have an impact on support for censorship: an increased trust in institutions may also result in increasing trust in censorship exercised by these institutions.

Political censorship seems to be more related to the Soviet past. Political censorship is supported more actively by the elites. The old thinking remains, but the direction is the opposite: the glorification of communism should be banned, likewise criticism of the Russian President. Political censorship, however, is much less prominent than moral censorship, and attitudes towards it are much more liberal.

The fact that Russian elites support political censorship more than ordinary people confirms that the elite is not ready for freedom and political competition, as Lilia Shevtsova (2007, p. 295) has aptly stated.

Different types of censorship can be seen to have relationships to different types of totalitarian mentality, as Vainshtein (1994, p. 256) has defined them. As some support the former totalitarian regime, some are adherents of authoritarian rule aimed at the creation of a market economy, while the democratic idea is generally compromised.

The generation shift may also reduce the support for censorship, but this will more likely cause a decline in moral rather than political censorship. Attitudes to some new phenomena have become paradoxically both more tolerant and even less tolerant, as is the case with attitudes towards religious sects (Levada, 2004).

On the other hand, it is worth noting that only a minority entirely support free publication of materials against ethnic groups even though Russian political culture has some elements of intolerance. Russians seem to be realizing dangerous opportunities for xenophobia, which may lead to dire consequences, taking into account the historical legacy of the country. Therefore, the many 
provocative attempts by nationalistic groups to fan the fire of hatred against national minorities are being regarded as a negative development by most of the population.

\section{Conclusion}

This study examined three different types of censorship found in Russia. These elements of censorship include moral censorship, political censorship, and the censorship of religious materials.

Moral censorship combines the censorship of obscenity (violence, nudity) as well as various new phenomena including non-traditional religions and advertisements. Moral censorship represents fear and rejection of new phenomena and seems to be related to political conservatism, as in the United States (Peek \& Brown, 1978). In Russia, however, moral censorship seems to be linked even more to age, and may therefore decline in the future.

Censorship of religious materials is a form of censorship that is more frequently found among the young than the old and is more common among men than women. This dimension of censorship seems to be the most non-traditional element of censorship, which is more supported by people who identify themselves as citizens of the world.

An individual support for censorship correlates with his/her experience of the overall political and economic changes in modern Russian society. Many individuals reject new phenomena such as pornography, sexual minorities, and non-traditional religions indiscriminately. In this respect, Russians support censorship when they become older or if they are poorly educated, live in smaller towns or in rural areas, and believe in God. Similar causalities have also been found in American support for censorship (Lambe, 2002).

In fact, Russians support the censorship of many issues mainly for the same reasons as do Americans. On the other hand, censorship of criticism of the Russian President, the glorification of communism, and of religious propaganda are seen as specific phenomena support for which is not directly connected to support for the censorship of other topics.

The prospects of support for censorship seem to be uncertain and ambiguous: the decline of non-conformism can be seen as a positive development, but at the same time there is also a growing willingness to condone violence and ethnic hatred. There is not, as could be expected, a negative correlation between opposition to censorship of information on sexual minorities on the one hand, and opposition to hate speech on the other. This sounds alarming, because with opposition to censorship on political issues more acceptable forms of censorship, such as that of violence and of hate speech, lose support. 


\section{References:}

Adorno, T. W., Frenkl-Brunswik, E., Levinson, D. J. \& Sanford, R. N. (1950). The authoritarian personality. New York: Harper \& Row.

Alexander, J. (1997). Surveying Attitudes in Russia. A Representation of Formlessness. Communist and Post-Communist Studies, 30, 107-127.

Belin, L. (2001). Political Bias and Self-Censorship in the Russian Media. In A. Brown (Ed.), Contemporary Russian Politics. A Reader (pp. 323-342). Oxford: Oxford University Press.

Belin, L. (2002). The Russian Media in the 1990s. Journal of Communist Studies and Transition Policies, 18, 139-160.

Dewhirst, M. \& Farrell, R. (Eds.), (1973). The Soviet Censorship. Metuchen, NJ: Scarecrow.

Dewhirst, M. (2002). Censorship in Russia, 1991 and 2001. Journal of Communist Studies and Transition Politics, 18, 21-34.

Dzirkals, L. (1982). Media Direction and Control in the USSR. In J. L. Curry \& J. R. Dassin (Eds.), Press Control around the World, (pp. 85-103). New York: Praeger.

Garnaghan, E. (2007). Out of Order. Russian Political Values in an Imperfect World. University Park, PA: Pennsylvania State University Press.

Lambe, J. (2002). Dimensions of Censorship: Reconceptualizing Public Willingness to Censor. Communication Law and Policy, 7, 187-235.

Lambe, J. (2004). Who Wants to Censor Pornography and Hate Speech? Mass Communication and Society, 7, 279-299.

Law of the Russian Federation No 2124-1, On the Mass Media, 27 December 1991. Article 3. Published in English in K. Nordenstreng, E. Vartanova \& Y. Zassoursky (Eds.), Russian Media Challenge (pp. 218-251). Helsinki: Kikimora.

Levada, Y. (2004). 'Chelovek Sovetskii': chetvertaya volna. Ramki samoopredeleniya ['The Soviet Man:' The Fourth Wave. The Limits of Self-determination]. Vestnik obshchetvennogo mneniya, 2004:3, 8-18.

Magun, V. \& Rudnev, M. (2008). Zhiznennye tsennosti rossiiskogo naseleniya: skhodstva i otlichiya v sravnenii s drugimi evropeiskimi stranami [Values of Life among Russian Population: Similarities and Differences in Comparison with Other European Countries]. Vestnik obshchestvennogo mneniya, 33-58.

McFarland, S., Ageyev, V., \& Abalakina-Paap, M. (1992). Authoritarianism in the former Soviet Union. Journal of Personality and Social Psychology, 63, 1004-1010.

Mikheyev, D. (1996). Russia Transformed. Indianapolis, IN: Hudson Institute. 
Mishler, W. \& Willerton, J. (2003). The Dynamics of Presidential Popularity in Post-Communist Russia: Cultural Imperative Versus Neo-Institutional Choice? The Journal of Politics, 65, 111-141.

Mishler, W. \& Rose, R. (2007). Generation, Age, and Time: The Dynamics of Political Learning during Russia’s Transformation. American Journal of Political Science, 51, 822-834.

Monitoring obshchestvennogo mneniya [Monitoring of Public Opinion] 2 (2004). 93-94 (the data are also available at http://www.wciom.ru/?pt=160\&article=819).

Nikula, J. \& Chernysh, M. (ed.) (2010). Social class in the Russian society: Studies in the social classes and social change of contemporary Russia. Saarbrücken: LAP Lambert Academic Publishing.

Peek, C. \& Brown, S. (1978). Pornography as a political symbol: Attitudes toward commercial nudity and attitudes toward political organizations. Social Science Quarterly, 58, 717-723.

Shevtsova, L. (2007). Russia-Lost in Transition. Washington DC: Brookings Institution.

Tilkidjiev, N. (2006). Post-Communist Structural and Values Inequalities: Occupational-Class Basis for Democratic Consolidation. Sociologija, 48, 113-136.

Vainshtein, G. (1994). Totalitarian Public Consciousness in a Post-Totalitarian Society: The Russian Case in the General Context of Post-Communist Developments. Communist and Post-Communist Studies, 27, 247-259.

WCIOM 6.7.2004: Rossiiskie SMI glazami obshchestva. Press-vypusk 99 [Russian Media in the Eyes of the Society. Press Release 99] (6.7.2004).

http://www.wciom.ru/?pt=160\&article=819 (accessed October 22, 2007);

WCIOM 4.8.2006: Dostup oppozitsii k SMI. Press-vypusk 508 [Access of the Opposition to Media. Press Release 508] (04.08.2006), http://www.wciom.ru/arkhiv/tematicheskiiarkhiv/item/single/2975.html (accessed October 22, 2007).

Zhirkov, G. (2001). Istoriya tsenzury v Rossii XIX-XX vv. [History of Censorship in Russia in 19th and 20th Centuries]. Moskva: Aspekt Press.

Zhurnalisty o Rossii, obshchestve i SMI [Journalists on Russia, Society and Media]. (2004). Available at http://www.monitoring.ru/off-line/news-images-new/all_russia.pdf (accessed March 17, 2006). 